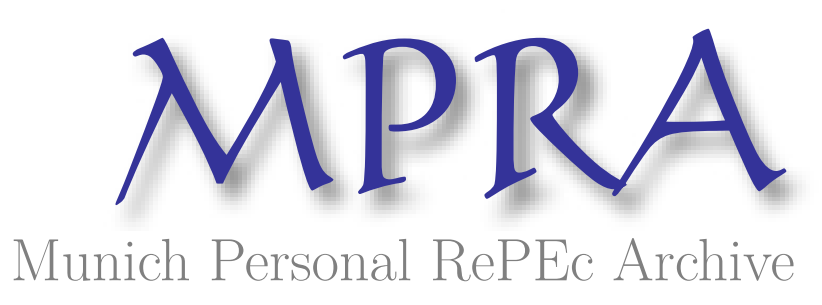

Corporate governance in the Netherlands

Bolt, Wilko and Peeters, Marga

De Nederlandsche Bank

1998

Online at https://mpra.ub.uni-muenchen.de/28694/

MPRA Paper No. 28694, posted 15 Feb 2011 20:12 UTC 


\title{
V. Corporate Governance in the Netherlands
}

\author{
WILKO BOLT AND MARGA PEETERS
}

\section{INTRODUCTION}

Corporate governance has become a topical issue and a main subject of intense academic and policy debates. It concerns the control of a corporation, in particular the relationship between the owners on the one hand and management and directors on the other hand. In a broader sense corporate governance is defined as the control of a corporation which concerns the interactions between all stakeholders, including employees, clients, local governments, etc.

Especially in the United States and the United Kingdom the owners of companies play an important role today. The influence of shareholders on management and directors is large and poorly performing corporations have clearly felt shareholders' pressure. The debate on governance nas also become important in other countries, even in those countries where shareholders do not have a crucial say in a corporation's decision making.

One reason for corporate governance being debated is the strong desire of - among others - the government to know who owns a country's corporations. This is definitely important for countries where shareholders have a decisive say, e.g. in the US. US shareholders are influential, shares are mainly in the hands of households and might be in the possession of a relatively small group of people. In Europe corporate governance has become an issue for another reason, namely as a part of the 'convergence' discussion. Many different systems exist, like the Anglo-Saxon model (UK), the German model (Germany), the Latin model (Spain and Italy) and the structure model (the Netherlands). ${ }^{1}$ Discussions today are about the wish to move towards the Anglo-Saxon model, which has as main characteristics transparency and no strict separation between the owners and the management of a corporation.

In the Netherlands this discussion is held also, fed by the discussions abroad. The Dutch situation is special in that Dutch shares are largely held by foreigners, as a consequence of the open character of the Dutch economy. Under a more Anglo-Saxon model of corporate governance more say would therefore be given to non-Dutch citizens. As in many other countries, another reason for the interest in corporate governance concerns the changing 
shareholding structures. Insurance companies and pension funds collect more and more funds that need to be invested profitably for the aging population. Investments in shares have become very common. Also, banks seem to change their (risky) investments behaviour. Allegedly more investments in shares by funds and banks take place but the reasons behind the specific investments choices and the enforcements of rights associated with shares are difficult to pin down. We do not know yet whether the increase in share investments have entailed ownerships of corporations that are more concentrated, nor do we know to what extent corporate behaviour or performance is influenced by the (new) developments in shareholding structures.

The literature on corporate governance is broad but the majority of studies discuss this issue only in a theoretical way. An empirical exception is Nickell et al. (1996), who investigate whether UK companies' performance is significantly affected by shareholders' governance, measured as a major shareholdership of one person outside a company. Some descriptive studies further exist, though for the Netherlands there is not much evidence. One study focusing on the Netherlands has been carried out by Gelauff and Den Broeder (1997). It is extensive in its presentation and presents some aggregate statistical evidence on corporate governance issues in comparison with Germany. The scarce evidence on Dutch corporate governance probably results from the fact that Dutch corporations do not have to give public notice on many issues.

An aim of this study is to answer first some simple questions about Dutch shareholding structures. For instance, the questions what the situation in the Netherlands is in comparison with other countries, and which investors' groups have changed their interest in shares investments are answered. We then concentrate on banks. ${ }^{2}$ Banks have a particular position in that they can be a lender to as well as an investor in a certain company. Their investments' possibilities in risky assets have always been restricted, in order to protect the bank's creditors, though these restrictions have been weakened since the early eighties. The information that we have can provide some insights in their portfolio investments' behaviour. In addition to this statistical evidence, the recent Dutch discussion on corporate governance is summarized. This provides information about the Dutch situation and could encourage an international discussion.

The outline of the paper is as follows. Section 2 presents the background information on corporate governance in a broad sense. Section 3 discusses the Dutch situation on shareholding on the basis of the available data. Section 4 provides more detailed information on shareholding by Dutch banks. Section 5 summarizes the current discussion about a recent proposal to move corporate governance in the Netherlands towards a more AngloSaxon model. Section 6 presents the conclusions. 


\section{BaCkground on Corporate Governance}

Ever since the notion that modern corporations are characterized by the separation of ownership and control (Berle and Means, 1933), the issue of aligning the interests of the owners and managers and other stakeholders - the main problem of corporate governance although the term 'corporate governance' was not coined until two decades ago - has given rise to a large academic literature and has been the subject of intense policy debate for quite some time. However, the discussion on corporate governance has recently attracted increased attention, originating in the US and UK at the end of the 1980s, and which by now has spread all over Europe.

There are several reasons for this. First, increased competitiveness of firms and corporations in a world where financial markets are becoming larger, more complex and more closely integrated than ever before, requires adequate governance structures to provide a proper framework for the exercise and control of power. The focus on the medium and long-term perspective makes good corporate governance vital. Second, the sharp increase in takeovers and management buy-outs in the 1980s in the US and the UK seems to have done more harm than good from an economic performance point of view. Third, a series of corporate failures (IBM, Rolls Royce, Barings, Maxwell, etc.) where the weakness of corporate governance was clearly one of the contributing factors adds to the picture. There is a growing common perception that managers have become insufficiently accountable to shareholders and other individuals or institutions that have stakes in companies (i.e. the stakeholders). It is argued that it is this unaccountability which provides the wrong incentives for managers, leading to short-term decision-making, and to a lack of long-run investing in physical and human capital and innovating businesses, which may ultimately have a negative impact on economic performance. In fact, we may say that corporate governance is foremost a matter of performance accountability (Demb and Neubauer, 1992).

These events and the widespread belief that corporate governance affects economic performance have spurred a public policy agenda and a variety of reforms. A good example is the so-called Cadbury Code in 1992 on corporate governance in the UK. Similarly, in the Netherlands we have had the Peters' Committee 1996 which has put forward a number of recommendations and suggestions for changing Dutch corporate governance structures (see also Section 5). These recommendations concern questions such as: how should directors of companies be selected, reappointed or disqualified; what should they be paid; what is the relationship between investors (stakeholders) and management; what are the rules in times of financial distress; how important are auditors and what responsibility do they have; what is the exact role of the 
Board of Directors and shareholders, etc. All these questions deserve attention in order to safeguard a proper framework of governance structures.

Basically, corporate governance can be described as the complete system of institutional arrangements and relations through which companies and financial institutions are directed and controlled. It presents the framework that governs the ability of economic agents (i.e. groups of persons or institutions) to manage corporate resources and it focuses on the crucial relationship between ownership, control and economic performance. The central problem of governance is to come up with an optimal system of relations which enhances the continuity of efficient business relationships in the presence of self-interested opportunistic agents, the stakeholders, by means of appropriate incentive schemes, safeguards and dispute resolution procedures (Kester, 1992). But who are the stakeholders in a company? Well-known categories of stakeholders are shareholders, creditors and managers, yet employees, suppliers and consumers are stakeholders as well. ${ }^{3}$

Research concerning corporate governance issues has developed along two lines. One line concerns the empirical content of the effects of corporate governance on economic performance. In such studies, corporate governance is for example measured by a degree of dominance of shareholders, or the size and/or composition (executive vs. non-executive members) of the Board of Directors, or the payment structure of management (e.g. stock option plans to link managerial effort to performance), or the frequency of proxy voting, etc. One is ultimately interested in the question whether different governance structures imply differences in corporate performance (see e.g. Nickell et al., 1996).

The other line concentrates on the theoretic modelling of corporate governance, especially on the application of principal-agent models. A first question which immediately comes to mind is why corporate governance issues should arise in the first place. In this context, Hart (1995) argues that corporate governance does matter in an organization whenever two conditions are present: an agency problem which concerns a conflict of interest among the stakeholders, and transaction costs such that this agency problem cannot be dealt with through a comprehensive contract. Hart claims that corporate governance plays an active role only when some future actions have not been specified in the initial contract: governance provides a way for deciding on these actions. However, in a complete comprehensive contracting world there are no 'residual' decisions, since everything has been specified in advance in the initial contract. In particular, corporate governance is concerned with the proper allocation of residual rights over the company's assets.

In general the goal of a company's management is to maximize the value of its financial assets. In order to carry out this task properly, management control of assets is separated from ownership of these assets. This separation enables the management to spread the risks over a large group of shareholders in 
attracting equity capital, and it facilitates the hiring of professional managers with more knowledge and expertise on management issues than the owners of assets in a company. However, too much separation and managerial discretion may induce the wrong incentives that underlie the basic principal-agent problem. Management might invest too much capital in projects that require little managerial effort or in projects that increase private gains, such as salaries, power and status. Hence, management must be monitored and be given the proper incentives in order to align management and investors' objectives. A major part of corporate governance is concerned with the design of checks and balances on managerial behaviour. Several mechanisms for controlling the management can be distinguished.

A first mechanism is provided by the Board of Directors which monitors the management and ratifies major decisions. In principle, the board plays a key role in monitoring; however, in practice its effectiveness may be limited due to all kinds of cross-relationships with the company itself. In this context, the Cadbury Committee recommends an independent member as chairman of the board and a formal selection procedure for non-executive directors. A second mechanism is presented by the shareholders themselves. They own the company in terms of the residual control rights, but they may have little or no incentive to monitor management. This is typically the case in the UK and the US where shareholders are numerous but not sufficiently influential to exert pressure individually. They face a significant free-rider problem: an individual shareholder can incur the cost of monitoring, while the benefits of the improved company performance accrue to all shareholders. So, almost no monitoring takes place. This problem is also present in the third mechanism device, namely proxy voting. Nobody wants to bear the cost of initially investigating the company's underperformance and launching the proxy fight, since the benefits from a better management are divided under all shareholders in the form of a higher share price.

As a fourth mechanism, given this free-rider problem associated with highly dispersed shareholders, one may argue that in order to improve corporate governance a company must have one or more dominant shareholders. Obviously, this reduces the free-rider problem but can create other difficulties at the same time. For instance, a company cannot enjoy the risk reduction benefits from portfolio diversification any longer and may also be subjected to costly trades with the large shareholder. Also, other agency problems may be introduced if the large shareholder is an institution itself with its own shareholders. Empirical evidence also confirms that large stakeholders play a mixed role in a company's performance (see e.g. Morck, Schleifer and Vishny (1988)).

To alleviate all these incentive and free-rider problems, one may take the view that hostile takeovers provide, in principle, a much more powerful mechanism to align the interests of the management and the other stakeholders in a 
company. It allows the individual who identifies an underperforming company to obtain a large reward, so there is basically no free-rider problem present. Therefore, one may argue that regulations which protect managers from hostile takeovers lower the disciplinary role of takeovers and may in the end be counterproductive. On the other hand, the enormous rise in the numbers of hostile takeovers in the UK and US in 1980s raised serious doubts as to whether it really improved economic performance in the long run. Further, increased competition between bidders in hostile takeovers may raise the price and lower profits from a takeover. Also the use of debt by the management as a way of committing itself not to 'empire-build' in the future raises the price of the company, which makes a takeover less likely. This last point makes it clear that the corporate financial structure also acts as a source of discipline on management.

The existence of debt in a company forces the management to use part of the revenues to make repayments. These debt obligations constrain the management's opportunities to invest in the wrong projects in terms of economic performance. So, debt finance acts as a discipline device. This reflects the important role of banks and other financial institutions in financing the business sector. It is often the case that banks, because of close relationships with companies, may be better informed than other providers of capital. Obviously, it is in their own interest that banks signal financial and economic crises at a early stage and, in response, enforce harsh restructuring plans in the firm. If management does not comply with their demands, banks can credibly threaten to withdraw their loans and to shut down the credit channel. This credibility depends to a large extent on the priority of debt finance. Without priority of debt finance, restructuring plans would not be carried out as soon as possible, which forces other providers of capital to demand higher rates of return. In this sense debt finance is complementary, since it allows the company to attract other sources of capital from financial markets at reasonable costs.

In literature there is some discussion on the combined position of banks as creditors/shareholders in a company. Banks often only worry about the downside risk of a firm, which could lead to too conservative or riskless behaviour and, in contrast, do not focus on the upside potential of a firm, which is usually the drive for the necessary innovations for continuity in the long run. Combining the two positions could lead to a better decision-making process. Moreover, the incentive to take too large risks with borrowed credit to benefit the shareholders is reduced if shareholders have issued debt to the firm at the same time. However, it is also argued that a combined creditor-shareholder position could undermine the discipline mechanism of banks on firms (Boot, 1994). If banks - apart from debt - do also have equity at stake in a firm, it makes it more difficult for them to act credibly in times of financial distress. 
TABLE 1

The structure of shareholding in selected countries (percentage of total, as at end of year)

\begin{tabular}{|c|c|c|c|c|c|c|c|}
\hline 1992 & $\begin{array}{c}\mathbf{G} \\
1990 \\
1995\end{array}$ & $\begin{array}{c}F \\
1992\end{array}$ & $\begin{array}{c}\text { I } \\
1993\end{array}$ & $\begin{array}{c}\text { UK } \\
1993\end{array}$ & $\begin{array}{c}\text { US } \\
1992\end{array}$ & $\mathrm{~J}$ & NL \\
\hline Institutional investors & 22 & 23 & 11 & 60 & 31 & 47 & 24 \\
\hline Banks & 10 & & 10 & 1 & 0 & 26 & 2 \\
\hline Pension Funds/Insurers & 12 & & 1 & 52 & 24 & 17 & 22 \\
\hline Others (Unit trusts) & & & 0 & 7 & 7 & 4 & \\
\hline Households & 17 & 34 & 34 & 19 & 48 & 23 & 19 \\
\hline Private Companies & 42 & 21 & 23 & 4 & 14 & 25 & 19 \\
\hline Public Authorities & 5 & 2 & 27 & 1 & & 1 & \\
\hline Foreign Investors & 14 & 20 & 5 & 16 & 7 & 4 & 37 \\
\hline
\end{tabular}

Note: The figures do not necessarily add up to 100 because of differences in definitions used by the providers of the data and differences in regulatory structures. A bank is a universal bank in Germany and a high-street bank in the UK.

Sources: Lannoo (1995, see Table 3, data for Germany, France, Italy, UK, US and Japan) and Annual Report of De Nederlandsche Bank (data for the Netherlands).

That is, the credibility of the threat to cut off the credit channel is reduced since it would also hurt the bank itself.

\section{Shareholding and Other Portfolio Investments in the NETHERLANDS}

This section presents some structures and trends in Dutch shareholding by various investors' groups. The main objective is to provide some insights into the changing shareholding structures in comparison with other countries and in comparison with other investment opportunities.

Table 1 shows the shareholding structures in Germany $(G)$, France $(F)$, Italy (I), the UK, the US and Japan (J), as published in Lannoo (1995, Table 3). In addition, data for the Netherlands (NL) are presented in the last column to make a comparison. Some caution is needed in comparing the figures as the year of measurement is not the same for each country and also the definitions of investor groups may slightly differ across countries. For the Netherlands it follows that institutional investors possessed 24 per cent of Dutch shares in 1995, of which 2 per cent by banks and 22 per cent by pension funds and insurance companies. Households and private companies each possessed about 19 per cent and with 37 per cent foreign investors possessed the major part. A comparison with the other countries shows that the Dutch shareholding structure resembles that in France most, although foreigners hold only 20 per cent 
of all shares in France. In none of the non-Dutch countries foreigners hold the majority of shares, which probably reflects the fact that these economies are less open than the Dutch one. The tiny percentage of shares held by banks in the Netherlands ( 2 per cent) is comparable with the situation in the UK and the US, but is in glaring contrast to Germany, Italy and in particular Japan. Banks in the latter countries are known to be involved in long-term relationships with companies and for this reason are larger stakeholders. The high share-ownership, i.e. 42 per cent, of private companies in Germany and of households, i.e. 48 per cent, in the US is also striking. For more information about these and other countries, see Lannoo (1995) and Mayer (1996).

We concentrate further on the Dutch situation. Figure 1 shows the development of the shareholders structure during 1980-1996. In this figure, banks, funds (insurance companies and pension funds), households and private companies, and foreigners are represented. The figure shows that banks own a small proportion and funds a large proportion of the total shares of about 2 per cent and 20 per cent, respectively. These shares remain quite constant over the whole sample period. It could be expected that institutional investors invest more in shares due to the fact that they possess more and more funds because of the aging population, as is observed in some other countries. But whereas the total value of shares, i.e. the market capitalization, has been multiplied by as much as five during 1980-1996, funds do not have a strongly growing part of the total share stock. Households and private companies, on the other hand, both have a strongly increasing part over the sample period. This is probably due to the increase in private pension schemes. The increase in shareholdership of households and private investors in the nineties turns out to have been wholly at the expense of foreign investors.

As Figure 1 does not reveal whether investors have shown a growing interest in share investments as such, some more detailed information is given. Figures 2 and 3 show the investments in domestic bonds, domestic shares, foreign shares and real estate by funds and banks, respectively. These investments are all risky and expressed here as a percentage of the total assets. Our main focus is domestic shareholding, although, foreign shareholding is shown to give an indication of the interest of domestic institutions in foreign investments. ${ }^{4}$ From Figure 2 it follows that investments in domestic and foreign shares, and domestic bonds are strongly increasing parts of the total assets of funds. For each of these risky assets, the proportion of the total assets in 1996 is even at least four times the proportion in 1980. From Figure 3 it follows that the strongly increasing pattern also holds for investments in all four risky assets by banks. Domestic bonds increased from 1.8 per cent in 1980 to 5.1 per cent in 1996, real estate from 0.1 per cent in 1980 to 0.3 per cent in 1996 and domestic shares from 0.22 per cent in 1980 to 0.75 per cent in 1996. As for funds, banks hold fewer shares than bonds. Investments in risky assets by banks seem 


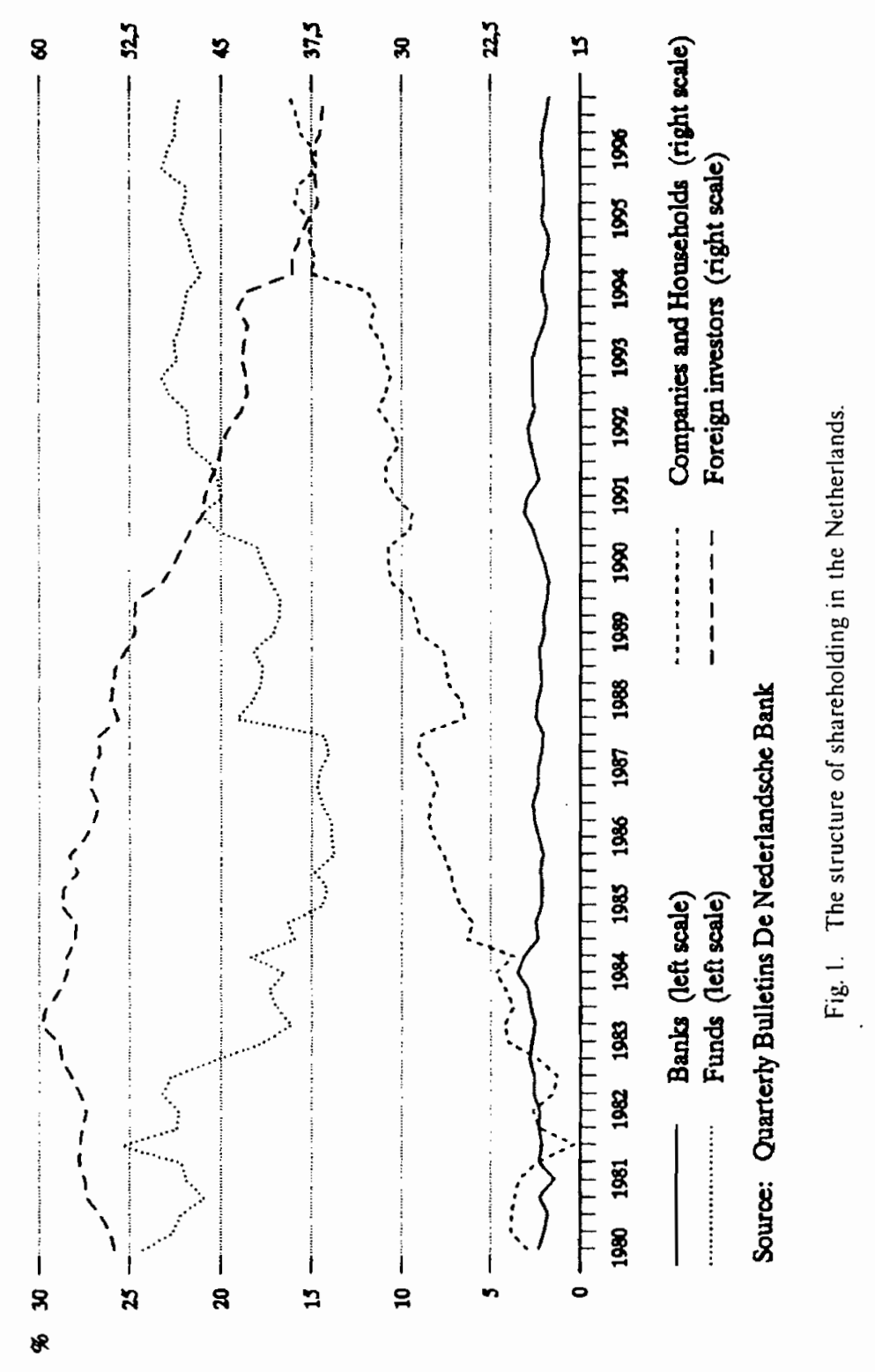




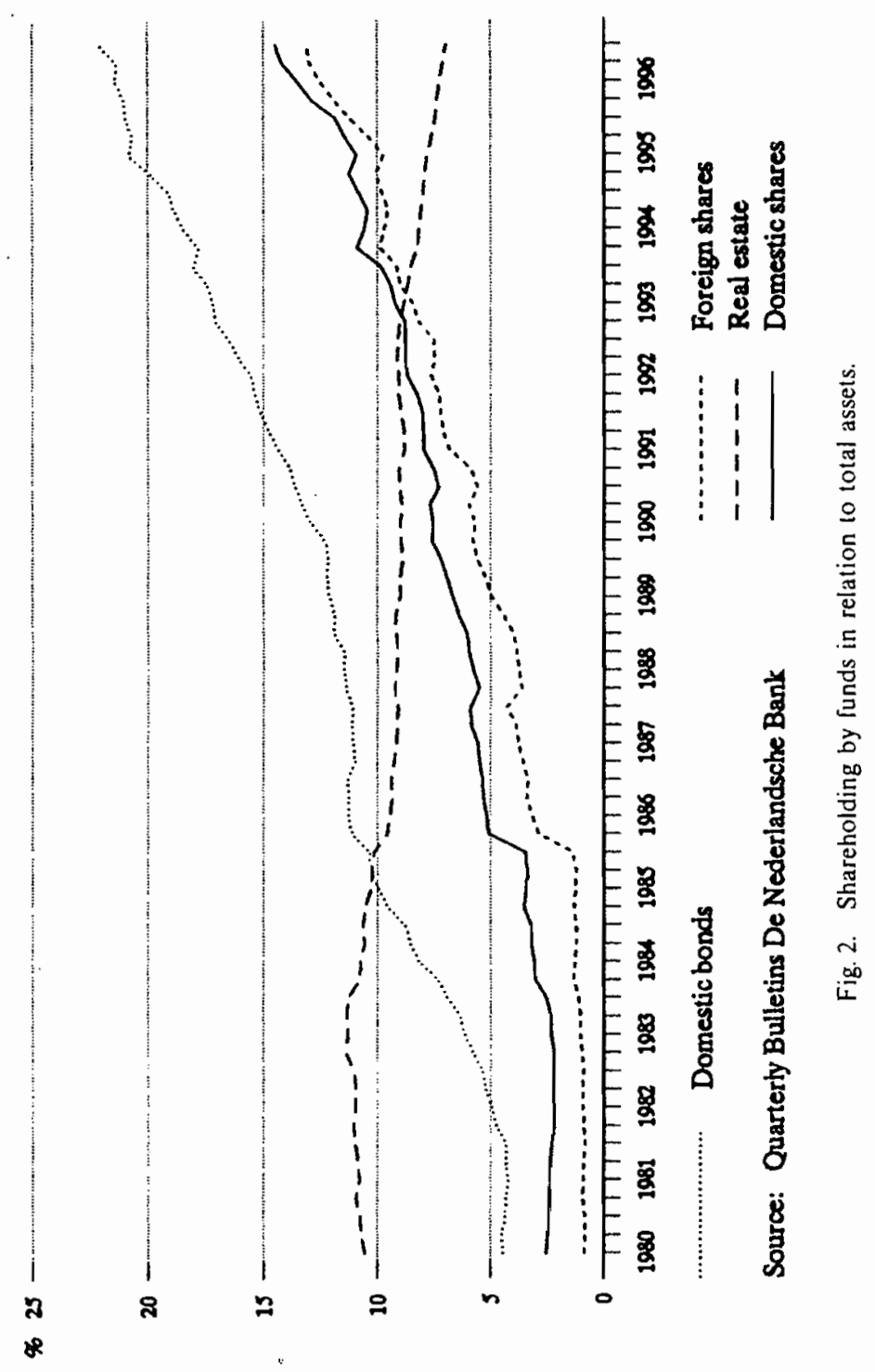




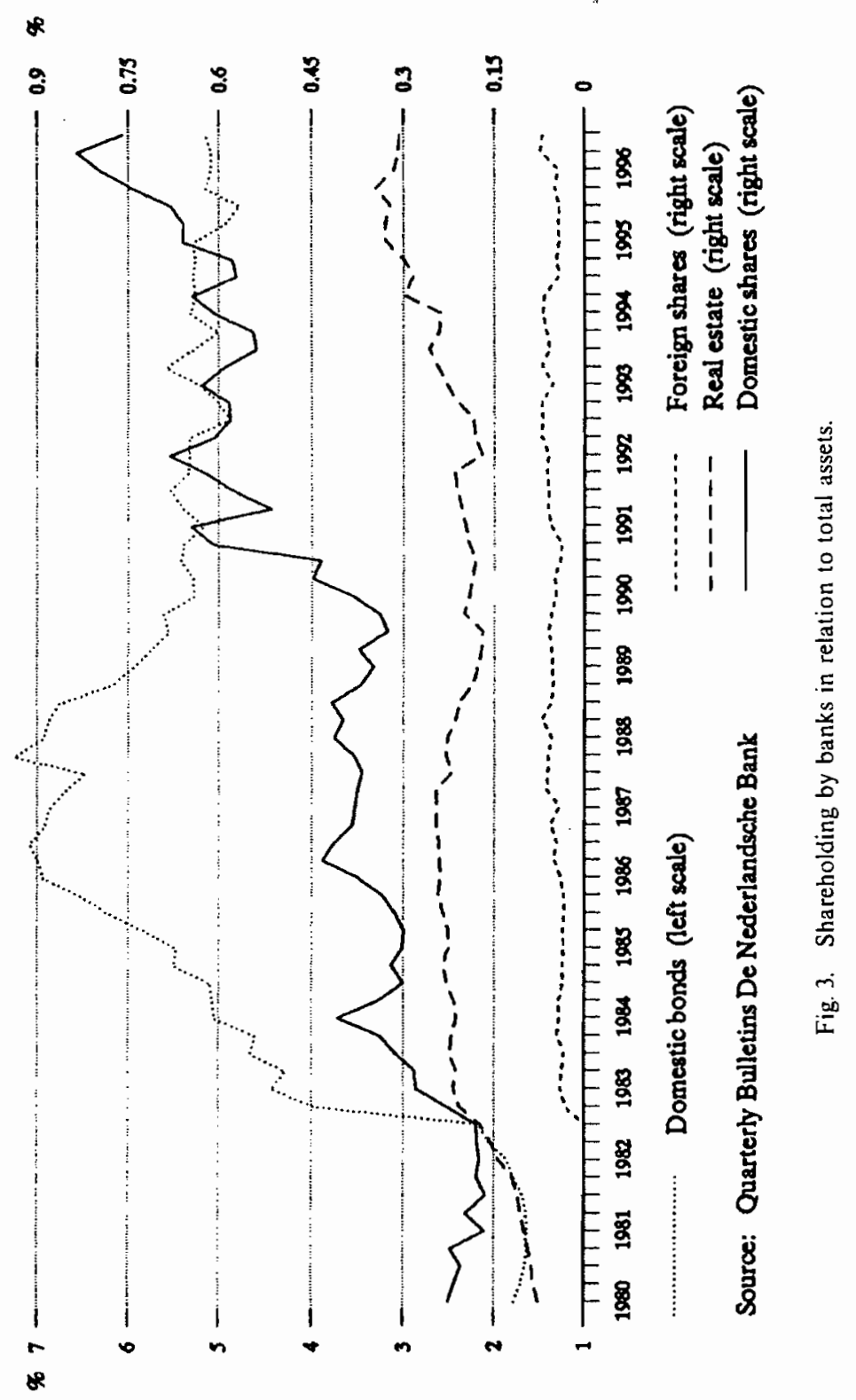


however overall lower than those by funds. This is due to stronger regulations for banks. For instance, banks are not allowed to invest excessively in risky assets. A solvency measure, known as the Cooke ratio, that was included in the 1988 Basle accords, ${ }^{5}$ necessitates an $\$ 8$ coverage of own equity for each $\$ 1$ investment in a risky asset. For banks foreign shareholding started in 1982 and is nowadays about 0.1 per cent of the total assets, as Figure 3 shows. In comparison with other countries, for instance the US, Dutch banks are large, so that the small percentages of $0.22-0.75$ per cent in domestic shares and 0.1 per cent in foreign shares can represent a large amount. It is also typical that, unlike German or Japanese banks, Dutch banks often only take equity positions in non-financial corporations under particular circumstances. ${ }^{6}$

To summarize, Dutch shares are mainly owned by foreigners (about 40 per cent) and funds (about 20 per cent). Only 2 per cent is in the hands of banks. Investments in risky assets by funds and banks relative to total assets have considerably increased during the sample period 1980-1996, among which share investments.

\section{InVESTMENTS By DUtCH BanKS}

Dutch banks possess a small percentage of the total Dutch shares but the shares' part of their total assets has grown during 1980-1996, as Figures 1 and 3 show. The deregulation that took place in the early eighties seems to be a main cause here.

Banks are impeded from excessive investment in risky assets to protect banks' creditors. Before 1980 a bank needed permission from the Dutch Central Bank for each participation of more than 5 per cent in a financial corporation. Investments in non-financial corporations were even prohibited until 1980. After 1980 the participation rule was relaxed to a 10 per cent participation. The participation has to be approved by the Ministry of Finance and in case of approval a 'certificate of no objection' ('vvgb' or verklaring van geen bezwaar in Dutch) is obtained via the Dutch Central Bank. This certificate is free of charge and - usually -- does not expire.

Figure 4 shows the numbers of certificates granted to banks during 1980-1996. A distinction is made between participations in financial and nonfinancial corporations. The figure shows that banks invest more in financial than non-financial corporations; in 1996 for instance, 500 and 150 certificates were granted for participations in financial corporations (see right scale) and non-financial corporations (left scale), respectively. The obvious reason for the discrepancy between the two types of investments is that linkages with financial corporations are stronger. Moreover, investments in non-financial corporations have only been allowed since 1980 . The certificates granted steadily increased 


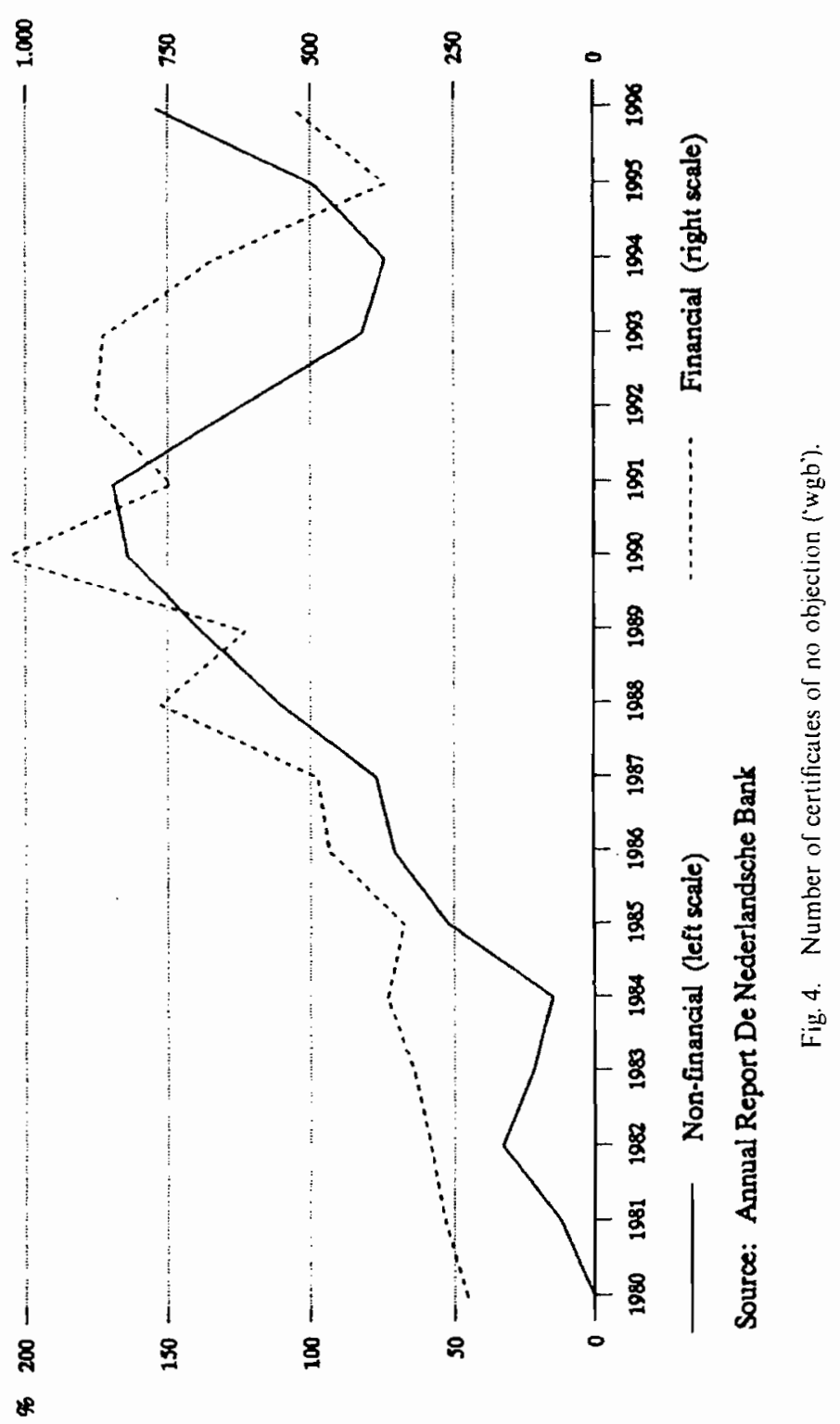


TABLE 2

Investments by Dutch banks in financial institutions (percentages)

\begin{tabular}{lcccc}
\hline Participation (\%) & 1993 & 1994 & 1995 & 1996 \\
\hline $11-20$ & 1 & 4 & 4 & 2 \\
$21-30$ & 2 & 3 & 4 & 4 \\
$31-40$ & 1 & 2 & 3 & 3 \\
$41-50$ & 3 & 3 & 8 & 6 \\
$51-60$ & 0 & 2 & 6 & 6 \\
$61-70$ & 1 & 2 & 5 & 1 \\
$71-80$ & 0 & 1 & 3 & 2 \\
$81-90$ & 0 & 0 & 2 & 76 \\
$91-100$ & 93 & 84 & 66 & 76 \\
\hline
\end{tabular}

Source: Quarterly reports and internal sources, De Nederlandsche Bank.

TABLE 3

Investments by Dutch banks in non-financial institutions (percentages)

\begin{tabular}{lcccc}
\hline Participation (\%) & 1993 & 1994 & 1995 & 1996 \\
\hline $11-20$ & 12 & 19 & 28 & 13 \\
$21-30$ & 19 & 33 & 21 & 16 \\
$31-40$ & 27 & 23 & 14 & 11 \\
$41-50$ & 23 & 14 & 10 & 15 \\
$51-60$ & 4 & 0 & 1 & 5 \\
$61-70$ & 8 & 1 & 2 & 2 \\
$71-80$ & 0 & 0 & 0 & 1 \\
$81-90$ & 0 & 0 & 1 & 1 \\
$91-100$ & 8 & 10 & 22 & 35 \\
\hline
\end{tabular}

Source: See Table 2.

until 1990 and slightly fell thereafter. More interesting are the participations in non-financial institutions as they concern investments in activities different from their banking activity. Figure 4 shows that the certificates for investments in non-financial corporations also increased strongly until 1990. So banks seem to have a growing interest in non-financial corporations. ${ }^{7}$

Along with each certificate granted by the Ministry of Finance it is known from 1993 onwards, what percentage of total shares of a corporation is bought by each bank. In Tables 2 and 3 figures are shown for investments in financial and non-financial corporations, respectively. ${ }^{8}$ Table 2 shows that only 1 per cent of all certificates concerned a participation between 11 per cent and 20 per cent in 1993. Also participations in the range 21-30 per cent, 31-40 per cent until 81-90 per cent were small. 
This holds true for all years, though rather less so for 1995 and 1996. The major part of participations thus concerns majority participations of more than 90 per cent, i.e. 93 per cent of all certificates in 1993, 84 per cent in 1994, 66 per cent in 1995 and 76 per cent in 1996. Table 3 gives a completely different story for investments in non-financial corporations. Only 8 per cent of all certificates concerns participations of more than 90 per cent in 1993, followed by 10 per cent, 22 per cent and 35 per cent in subsequent years. Most participations are small. For instance 12 per cent, 19 per cent, 28 per cent and 13 per cent in 1993 until 1996 concerned participations of only 11 per cent to 20 per cent. A major participation of banks in non-financial institutions, in that more than 50 per cent of the total shares of the corporation under consideration were bought, holds for 20 per cent of the total bank investments in 1993, and 11 per cent, 26 per cent and 44 per cent in subsequent years. Majority participations are hence strongly increasing over time.

From these figures it follows that banks' main share investments concern financial corporations and that the participation is high. Banks' share investments in non-financial corporations are mainly minority. Majority participations however increased from 20 per cent in 1993 to 44 per cent in 1996. Possibly more companies temporarily lodged their shares at a bank (before issue), or otherwise, banks became involved in companies as shareholders when the companies were unable to pay back their loans. Other possible reasons for the increase in non-financial participations are higher returns on these share investments and/or possibilities of management. We can assume that management is more likely to take place in case of majority participations but the data do not reveal whether this has been a motivation for investing in the particular corporation. It is also noticeable that participations are either low or high, and not about 61-90 per cent. This might be explained from the point of view that a participation of more than 60 per cent is a majority and hence almost equal to possessing and/or running the whole corporation.

As said before, the figures in Tables 2 and 3 concern the certificates of no objection for a participation of more than 10 per cent granted to banks during a certain year. These figures provide information neither on the duration nor on the withdrawal of the participation. A participation of 11 per cent in January 1993, for instance, that lasts a couple of months is measured in the same way as a participation of 11 per cent that lasts forever. Moreover, Tables 2 and 3 do not provide information on small participations of less than 10 per cent.

More specific information is given in Table 4. The data presented concern all participations of ten major Dutch banks that cover about 90 per cent of all Dutch banks (in terms of assets). For each bank the participations are subdivided in 10 categories for 1994 and 1995, as in the previous tables. In contrast with the figures in Tables 2 and 3 that concern participations during a whole year, these figures concern stock data measured at the last day of the year. 
TABLE 4

Investments by ten Dutch banks (percentages)

\begin{tabular}{lrr}
\hline Participation (\%) & 1994 & 1995 \\
\hline $0-10$ & 14 & 14 \\
$11-20$ & 4 & 5 \\
$21-30$ & 3 & 3 \\
$31-40$ & 2 & 2 \\
$41-50$ & 5 & 5 \\
$51-60$ & 1 & 1 \\
$61-70$ & 1 & 1 \\
$71-80$ & 1 & 1 \\
$81-90$ & 0 & 1 \\
$91-100$ & 69 & 68 \\
\hline
\end{tabular}

Figures reported are the averages of ten large banks in the Netherlands.

Source: Internal sources, De Nederlandsche Bank.

Hence, a participation of more than 10 per cent by one of the ten major banks for which a certificate was granted in 1994 or 1995 is included in Tables 2 or 3 , and also in Table 4. Participations in Table 4, though, also cover small ones and can include participations that were granted before 1994.

The figures in Table 4 show that about 70 per cent of all participations exceed 90 per cent in 1994 and 1995. This is a large majority of the total participations and resembles the figure for investments in financial institutions reported in Table 2. Table 4 does (unfortunately) not distinguish between financial and non-financial institutions but probably the major part of the 91-100 per cent participations concerns financial institutions. In only one out of the ten banks under consideration majority participations do not prevail, indicating that the influence of banks in most corporations where it is a shareholder can be large. It is also very clear from Table 4 that mainly small participations occur, as a second choice after majority participations of 91-100 per cent. Participations of $0-10$ per cent equal 14 per cent on average, although across the ten banks this percentage varies from 3 per cent to 36 per cent. As in Tables 2 and 3 it thus follows from Table 4 that participations in 1994 and 1995 are either very high, in which case exerting influence seems evident, or very small, in which case managerial intentions seem weak. Between the two years under investigation, not many differences in the distributions exist. The total number of participations, however, clearly changes. Seven banks increase this number, ranging from 3.1 per cent to 46.6 per cent, the other three banks decrease it, ranging from 2 per cent to 21.4 per cent, whereas the overall increase is 5 per cent. The shares investments behaviour in 1994 and 1995 thus clearly differs. 
To summarize, banks have mainly majority participations of more than 90 per cent in financial corporations and mainly minority participations in non-financial corporations. From 1993 until 1996, though, majority participations in non-financial corporations have increased from 20 per cent to 44 per cent. Data from ten individual banks for 1994 and 1995 show participations of either 0-50 per cent or 91-100 per cent. These banks have increased their share investments by 5 per cent on average.

\section{The Recent Discussion on Dutch Corporate Governance}

Last year attention was drawn to corporate governance in the Netherlands by a report of a committee chaired by former Aegon chief executive R. F. M. Peters (1996). The committee was set up by the Dutch Association of Stockbroking (Vereniging van Effectenhandel in Dutch) and had as its main task to (re-)consider aspects of corporate governance in the Netherlands, i.e. relationships between supervision, management and the providers of financial means of Dutch corporations. Social and environmental aspects were not considered. The advice of the committee on possible future changes in current corporate governance was given in the report whose main intention is to provide some recommendations and initiate a general discussion.

Several reasons underlie the study of Dutch corporate governance. On the one hand are the expanding international character of the Dutch economy and changing international relations. On the other hand are a renewed interest in the value added of corporations and an increasing international attention on the role, position and influence of providers of financial means. The changing structures of the investors in shares in recent years, as shown in Section 3, were also crucial.

A similar study was carried out under the chairmanship of Sir Adrian Cadbury in the United Kingdom in 1992, whose results are given in the Cadbury report. The study was a response to a number of bankruptcies of corporations in the United Kingdom. This is unlike the Peters study although several bankruptcies of companies have also occurred in the Netherlands in recent years. As one of the first in Europe the Cadbury report recommended more transparency in the structure of corporations. Moreover, much more influence can nowadays be exerted by shareholders.

The Peters report gives advice concerning the composition, task, appointment, remuneration and procedure of the Supervisory Board and the Board of Directors. The main finding of the report is that there are reasons to increase the influence of shareholders under normal circumstances, in many cases. There is an appeal for the boards and shareholders of each corporation to reconsider the influence of the shareholders. Some criteria are reported and 
it is suggested that the corporation's considerations along with these criteria should be discussed at the General Meeting of Shareholders of each corporation in 1998. A report on the compliance with the recommendations, the discussions and the conclusions of the meeting should be made, but which institution will be in charge of this report has not been defined. The report also recommends that buying own shares in the Netherlands should be possible. Currently strong fiscal restrictions exist that should be weakened in view of the treatment of this issue in other countries.

In the report the procedures for the Supervisory Board, Board of Directors and the most important, the General Meeting of Shareholders, are laid out concisely. The recommendations for changes are clear, although in most respects difficult to define precisely. This is in general a problem with corporate governance and as a consequence of this, it is hard to verify whether managers comply with the desires and recommendations of shareholders or not.

The Peters committee, though, states the necessity for the management to give account to shareholders under any circumstances. The report is seen as an appeal for an Anglo-Saxon model instead of the current Dutch 'structure'system, because in essence more influence for shareholders and transparency are desirable. A first principle is that the adage 'one share, one vote' holds, implying that a shareholder has a say proportional to his number of shares. A second principle is that the management should give a clear and transparent account to shareholders. In some situations, however, exceptions may occur. An example is the case where a only few shareholders attend the meeting of shareholders, which means that they are able to exert an influence that is disproportionally large. In such a case the committee justifies priority shares or certain certificates. A further assumption of the committee is that the more shareholders attend the shareholders' meeting, the higher the 'quality' of decision making is and hence less need for deviating from the 'one share, one vote' rule. In order to achieve continuity of decision making, a representative shareholders' meeting is deemed necessary by the committee. For this reason shareholders, in particular institutional and other large investors, are urged to show up and have a say at the meeting. An efficient proxy soliciting system seems moreover also important. Small shareholders can in this way - without additional costs - be represented at the meeting by a person who votes in their interest.

Six concrete points are mentioned to test the role and influence of shareholders. The first is the strategic policy of the corporation, such as the growth prospects, the risk profile and the desired profit level. The second concerns a major change in the nature and the extent of the corporations. The third is the dividend policy. The fourth is the extent and composition of the total shares, such as forthcoming issues, priority rights, etc. The fifth concerns changes in statutes and the sixth the arrangement and approval of the annual accounts. 
The report on corporate governance contains many more points but our summary stops here. Criticisms that have been made, mainly in comments in the press, concern the points mentioned above. Some of them are positive, some (strongly) negative. We briefly outline some here.

The strong preference of the current Dutch model to the Anglo-Saxon model arises from the idea that shareholders have a lasting and quick return as an objective instead of a say in the corporation. The Anglo-Saxon model therefore might only lead to more profitability in the short run. Moreover, institutional investors, such as investment and pension funds, let alone private investors, are not seen as professionals that can manage a corporation. In the AngloSaxon model the power rests with the shareholders' meeting that is seen as an anonymous, amorphous group of people. This is in sharp contrast with the Dutch model where the Supervisory Board, characterised as independent and personally responsible, has the main power. Also, the fact that the cooption system of the Supervisory Board will be curtailed, i.e. the Supervisory Board no longer appoints (all) new members, makes it possible for employees to have a say. As such, the Supervisory Board is no longer independent and confidential, and clear separations between boards, employees and shareholders can no longer exist. Another objective against increasing the role of shareholders is the argument that shareholders already have a considerable say in corporations. This is based on findings from a questionnaire among 538 general directors held in 1996 (see NIVE, 1997). It shows that in strategic decision making the wishes and expectations of 65 per cent of the shareholders were taken into account, 2 per cent more than of employees. The opinions of 65 per cent of the representatives of shareholders, hence a large majority, also already contribute to important management decisions. From another survey among Dutch Chief Financial Executives by Cools (1993, Chapter 6) it appears that shareholders are the principal stakeholders in 8 per cent of all cases. No hierarchy has 52 per cent, customers 22 per cent, employees 14 per cent, suppliers 4 per cent and shareholders hence 8 per cent.

The preference of the Anglo-Saxon model to the current Dutch model, on the other hand, is expressed by another group. A bottleneck of the current system is said to be the cooptation-system which hampers shareholders from having a crucial say. The viewpoint of the Peters committee is upheld and by some even not found sufficiently far-reaching. Legal regulations, instead of having corporations making decisions themselves as the Peters report suggests, should force corporations to follow the suggestions made in the report.

To summarize, the recent Dutch report on corporate governance that expresses the wish for a more Anglo-Saxon model where shareholders have more impact, has triggered a lot of discussion. Many people seem to offer resistance because of various reasons, but of course, there are two sides to every coin. In order to reach a solution it seems important to gather more 
information on the current situation of Dutch firms. This could clarify what the position of stakeholders today is, and what the opinion of all stakeholders is on giving more responsibility to shareholders in the decision making process. It seems moreover important to consider the different types of shareholders. The situation where banks are the main shareholders could be different from the situation where, for instance, households are the main shareholders. The particular position of banks as debtholder and shareholder could play a role in this matter.

\section{SUMmary and Conclusions}

The focus in this paper has been on the Dutch situation of changing shareholders' structures, participations by banks and the current discussion on a possible move towards a more Anglo-Saxon model where shareholders have an important say. Statistics show that there has been an increasing interest in equity investment, in general probably because shares have been profitable in comparison with other investment possibilities. For funds and banks equity investment as a part of total assets has tripled during 1980-1996. The deregulations in the early eighties and the increasing share values during 1992-1996 can have played a role here. Remarkably, banks have increased their majority participations in non-financial institutions from 20 per cent in 1993 to 44 per cent in 1996, thus showing a strongly growing part in non-banking activities.

The recent Dutch discussion on changing the Dutch structure system of corporate governance is lifely and important. In cases where the main rules of the Anglo-Saxon model are accepted, shareholders will be given a lot of influence, and the Boards of Directors and the Supervisory Boards relatively far less than they have today. This could be far-reaching, in particular in the Netherlands where about 40 per cent of all shares are owned by foreigners who might not have adequate knowledge of the Dutch corporation and its economic environment. Moreover, the (domestic or foreign) investor's interest in equity investment might be more concerned with the high profitability of shares (in comparison with other investments) rather than the possibilities of governance. Under an Anglo-Saxon model an important say would be given to investors with basically short-term profitability objectives instead of a profound knowledge of the corporation and its environment.

Much more information is however needed to investigate the Dutch case. It would be interesting to have more insights in the investors' reasonings behind equity investment. The question whether governing or short-term profitability is the main motivation, could then be answered. In addition, it would be interesting to study the current impact of shareholders on the performance of 
corporations in much more depth. But in order to do this, (more) information on corporations and their shareholders should become publicly available.

\section{Notes}

1. The list is not complete, one reason being that the distinction between the various models and matching count ries is not clear-cut.

2. The choice for banks comes among others from the availability of data.

3. Broadly construed, three types of stakeholder relationships can be distinguished: corporate gorernance, i.e. the relation between shareholders and management, contractual gocernance, i.e. the relation between different companies, and work goternance, i.e. the relation between employees and management.

4. See also Sparling (1997) on invest ments in both shares and bonds. Dutch and foreign, by foreign and Dutch investors.

5. See for instance Dewatripont and Tirole (1994) on the precise definition; the background and implications for banking.

6. On the sizes of Dutch banks and their equity positions, see Cools (1993, chapter 5)

7. Some caution is needed here as banks might be involved in share issues by other corporations.

8. For 1993 not all participations are known. We assume here that the restricted sample available is representative for all certificates granted in this year.

\section{REFERENCES}

Berle, A. and G. Means (1933) The Modern Corporation and Pricate Property, Macmillan. New York.

Boot. A. W. A. (1994) De Financiering can het Bedrijfslecen: Tussen Structuurregime en Financiële Sector (in English: Financing Private Companies: Between Structure Regime and Financial Sector), Amsterdam University Press, University of Amsterdam.

Cools, K. (1993) Capital Structure Choice, Unpublished thesis, University of Tilburg.

Cubbin, J. and D. Leech (1983) The Effect of Shareholding Dispersion on the Degree of Control in British Companies: Theory and Measurement. The Economic Journal 93, 351-369.

Demb, A. and F. Neubauer (1992) The Corporate Board: Confronting the Paradoxes, Oxford University Press, Oxford

Dewatripont, M. and J. Tirole (1994) The Prudential Regulation of Banks, The MIT Press, Cambridge, Massachusetts.

The Economist (1994) A survey of corporate governance.

Gelauff. G. M. M. and C. Den Broeder (1996) Governance of Stakeholder Relationships: The German and Dutch experience, SUERF Studies No. 1.

Hart. O. (1995) Corporate Governance: Some Theory and Implications, The Economic Journal $105.678-689$.

Kester, W. (1992) Industrial Groups as Systems of Contractual Governance, Oxford Retiew of Economic Policy 6, 24-44.

Lannoo, K. (1995) Corporate Governance in Europe, CEPS Working Party Report No. 12, Centre for European Policy Studies, Brussels.

Mayer, C. (1996) Corporate Governance, Competition and Performance. OECD

Economics Department Working Papers. No. 164, Paris. 
Morck, R., A. Schleifer and R. Vishny (1988) Management Ownership and Market Valuation: An Empirical Analysis, Journal of Financial Economics 20, 293-315:

Nickell, S., D. Nicolitsas and N. Dryden (1996) What Makes Firms Perform Well?, paper presented at the European Economic Association meeting in Istanbul.

NIVE (Nederlandse Vereniging Voor Management) (1997) NIVE-enquête 1996.

Peters, J. F. M. et al. (1996) Corporate Governance in Nederland: Een Aanzet lot Verandering en een Uitnodiging tot Discussie (in English: Corporate Governance in the Netherlands: Initiative to Change and an Invitation for Discussion), report by The Commission Corporate Governance installed by The Association of Stokebroking.

Sparling, R. P. (1997) Beleggen in het Buitenland (in English: Investments in Foreign Countries), Economische Statistische Berichten, nr 4093. 